\title{
The role of prescribed fire in the provision of regulating ecosystem services of Spanish heathlands
}

\author{
Leonor Calvo, Sara Huerta, Elena Marcos, Javier Calvo-Fernández, Angela Taboada
}

Area of Ecology, University of León, 24071 León, Spain, e-mail: leonor.calvo@unileon.es

\begin{abstract}
We provide a synthesis of evidence of the effects of burning and $\mathrm{N}$ deposition on the provision of regulating ecosystem services of Cantabrian heathlands (NW Spain). We quantified carbon sequestration in litter, above and belowground biomass, root and soil compartments in heathlands after burning and burning plus $\mathrm{N}$ fertilization.
\end{abstract}

Key words: Carbon sequestration, prescribed burning, nitrogen deposition, Cantabrian Heathlands.

\section{Introduction}

Global change may affect the dynamics of ecosystems and the goods and services they provide (Wessel et al., 2004). Atmospheric nitrogen $(\mathrm{N})$ deposition is one of most important drivers of global change, mainly in temperate ecosystems (Valladares et al., 2005). Heathlands are widespread across Europe and have been identified by the IPCC as an ecosystem vulnerable to global changes (IPCC (2007).

Heathlands are typical man-made ecosystems in Europe that require some sort of management activities (cutting, burning, etc.) to preserve them. These ecosystems usually have a high natural value and, in the last few decades, they have suffered from lack of management, wildfires or size reduction. Atmospheric $\mathrm{N}$ deposition may add to these threats and make these ecosystems even more at risk. Heathlands in the Cantabrian Mountains occur on nutrient-poor acidic soils and are functionally adapted to low $\mathrm{N}$ content in the soil. So, the addition of $\mathrm{N}$ via deposition has the potential to affect their structure, functioning and, therefore, could affect the provision of regulating ecosystem services such as carbon sequestration and storage (de Vries et al., 2009). However, literature information suggests that the impact of $\mathrm{N}$ deposition on ecosystem carbon sequestration is highly uncertain (de Vries et al., 2009).
Management strategies developed in heathlands, such as burning, produce changes in plant community composition and rejuvenation of Calluna vulgaris plants, which affect their carbon sequestration capacity (Kopittke et al., 2013).

In this paper we aim to evaluate the impact of management strategies (prescribed burning) in the framework of $\mathrm{N}$ deposition on the regulating ecosystem services (capacity of carbon sequestration) provided by Cantabrian heathlands. We try to answer the following questions: 1) Does prescribed burning have a positive effect on carbon sequestration in heathlands? 2) Does increased $\mathrm{N}$ deposition have the potential to alter carbon storage after burning in heathlands? 3) Which is the main ecosystem compartment for carbon storage in heathlands?

\section{Materials and Methods}

The study area is located in the Cantabrian Mountains (NW Spain). Three heathland sites (2-4 ha) were selected: San Isidro $\left(1636 \mathrm{~m}, 4^{\circ} 03^{\prime} \mathrm{N}, 5^{\circ} 21^{\prime} \mathrm{W}\right)$; Riopinos I (1653m, $\left.43^{\circ} 02^{\prime} \mathrm{N}, 5^{\circ} 24^{\prime} \mathrm{W}\right)$; Riopinos II (1567m, $43^{\circ} 02^{\prime} \mathrm{N}, 5^{\circ} 26^{\prime}$ W). The soil of these sites is acidic with low fertility. Vegetation is characterised by Calluna vulgaris as a dominant 
species, Erica tetralix and Vaccinium myrtillus as the accompanying ones.

We placed three permanent plots $(20 \mathrm{mx} 20 \mathrm{~m})$ in each heathland site. In June 2005, one plot per site was subjected to an experimental fire (burned plot), the second one to experimental fire plus yearly fertilisation until 2014 (burned plus fertilized plot), and the last one was used as a control. The fertilizer level, $5.6 \mathrm{gm}^{-2} \mathrm{yr}^{-1}$, was chosen to simulate twice the estimated current background pollution level in the area. In 2014, a total of three $1 \mathrm{~m}^{2}$ sampling units were studied in each plot (i.e. 9 replicates per treatment). In each sampling unit the aboveground plant biomass was harvested separately for each woody and herbaceous species. In the case of $C$. vulgaris we differentiated (a) leaves, (b) stems, and (c) belowground biomass. A sample of litter was taken for each sampling unit. Three $5 \mathrm{~cm}$ diameter soil cores were sampled in each sampling unit and two soil layers were differentiated: upper $(0-10 \mathrm{~cm})$ and lower $(10-25 \mathrm{~cm})$. The bulk density of each layer was calculated. A sample of litter was taken from each sampling unit and its volume recorded. Total amounts of carbon were calculated in plants, litter and soil layers (upper and lower) for control, burned and burned plus fertilized plots.

The harvested vegetation and litter was fully dried at $40{ }^{\circ} \mathrm{C}$ for $48 \mathrm{hrs}$, ground with a mixer mill and sieved $(200 \mu \mathrm{m})$. Soil samples were air dried, ground and sieved $(200 \mu \mathrm{m})$. Both vegetation, litter and soil samples were analysed for total carbon (C) using an elemental analyser (Carlo Erba NA 1500)

One way analysis of variance including treatment as fixed factor were performed for the carbon storage in each of the compartments. Where pairwise comparisons were needed the post hoc test Tukey was used. All data were analysed using statistical package SPSS statistics (version 21).

\section{Results and Discussion}

Aboveground biomass in Calluna vulgaris was higher than in the other woody species, both in the control and after experimental treatments. Erica tetralix showed a significant increase in aboveground biomass after burning and fertilization, while the rest of the woody species did not show any significant variation.

The vast majority of the total carbon was allocated in the Calluna stems in the control situation (Table 1). However, this pattern was modified after burning and fertilization. There was a significant increase in the carbon content of leaves $\left(\mathrm{F}_{2,24}=5.36 ; \mathrm{p}<0.05\right)$, and a reduction in the other two compartments (stems $\left(\mathrm{F}_{2,24}=44.83 ; \mathrm{p}<0.05\right)$; and roots $\left(\mathrm{F}_{2,24}=24.89 ; \mathrm{p}<0.05\right)$ after burning and burning plus $\mathrm{N}$ fertilization.
Table 1. Average proportion of total carbon in the different Calluna vulgaris compartments (leaves, stems and roots) in control plots and after experimental treatments. (Different letters mean significant differences among treatments for each compartment)

\begin{tabular}{|c|c|c|c|}
\hline & Leaves & Stems & Roots \\
\hline Control & $24 \% \mathrm{a}$ & $49 \% \mathrm{a}$ & $27 \% \mathrm{a}$ \\
\hline Burned & $40 \% \mathrm{~b}$ & $38 \% \mathrm{~b}$ & $22 \% \mathrm{~b}$ \\
\hline Burned + N Fertilization & $43 \% \mathrm{~b}$ & $37 \% \mathrm{~b}$ & $20 \% \mathrm{~b}$ \\
\hline
\end{tabular}

The average carbon storage in all the compartments of these heathlands is 122 tonnes/ha (Fig. 1). Soil horizons are the most important compartment of sequestrated $\mathrm{C}$ in the control situation and after burning and $\mathrm{N}$ fertilization. Furthermore, soil horizons showed the highest carbon storage after burning plus $\mathrm{N}$ deposition, although without significant differences $\left(\mathrm{F}_{2,24}=60.91 ; \mathrm{P}=0.32\right)$. However, carbon storage in vegetation $\left(\mathrm{F}_{2,24}=36.10 ; \mathrm{P}<0.05\right)$ and litter $\left(\mathrm{F}_{2,24}=17.34 ; \mathrm{P}=0.00\right)$ showed a significant decrease after burning and burning plus fertilization. The lower soil layer showed higher $\mathrm{C}$ accumulation (72.46 tonnes/ha) than the upper one (51.14 tonnes/ha).

In general, the compartment of soil horizons shows the highest capacity for carbon storage in Cantabrian heathlands as occurs in other heathlands in Europe (de Vries et al., 2009). Traditional management (burning) does not affect the carbon distribution pattern. However, burning in the framework of $\mathrm{N}$ deposition increases the capacity of Cantabrian heathland carbon sequestration compared to the control situation. Burning involves a rejuvenation of the Cantabrian heathlands and facilitate a net carbon gain

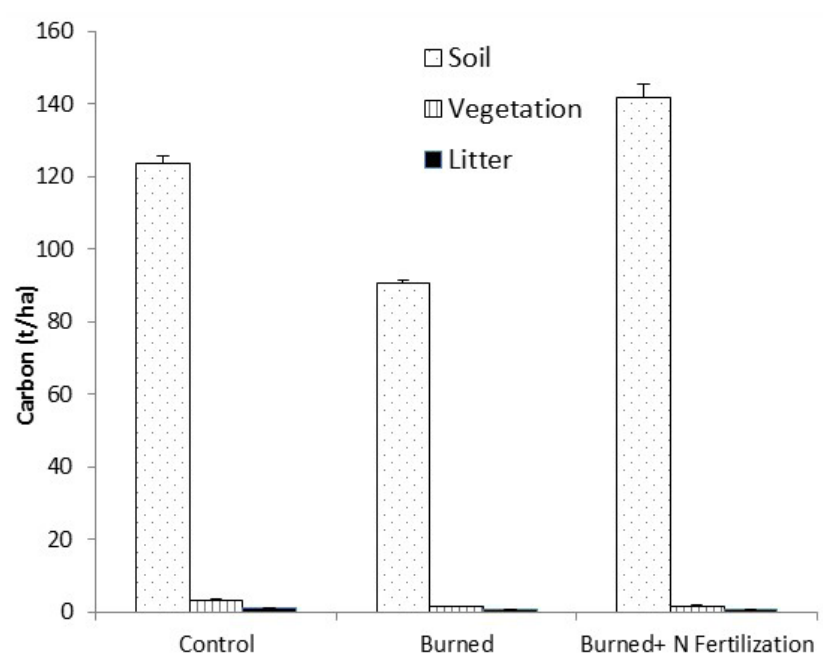

Figure 1. Average and standard error of carbon (tonnes/ha) within soil, aboveground vegetation and litter in control, burned and burned plus fertilized heathland plots 
(Kopittke et al., 2013). Some authors such as Ostle et al., (2009) indicated that traditional management land use is the most important short-term determinant of landscape carbon stocks and sequestration.

\section{References}

De Vries, W., Solberg, S., Dobbertin, M., Sterba, H., Laubhann, D., Van Oijen, M., Evans, C., Gundersen, P., Kros, J., Wamelink, G. W. W., Reinds, G. J., Sutton, M. A., 2009, The impact of nitrogen deposition on carbon sequestration by European forests and heathlands, Forest Ecology and Management 258: 1814-1823.

IPCC (2007) Chapter 12: Europe. In: Parry ML, Canziani OF, Palutikof JP, van der Linden PJ, Hanson CE (eds) Contribution of Working Group II to the Fourth Assessment Report of the Intergovernmental Panel on Climate Change. Cambridge University Press, Cambridge
Kopittke, GR., Tietem, A., van Loon EE., Kalbitz, K., 2013, The age of managed heathland communities: implications for carbon storage? Plant Soil 369:219-230.

Ostle, N.J, Levy, P.E., Evans, C.D., Smith, P. 2009. UK land use and soil carbon sequestration, Land Use Policy 26S: 274-283.

Valladares, F., Peñuelas, J., De Luis Calabuig, E. 2005. Impactos sobre los ecosistemas terrestres. En: Evaluación preliminar del impacto en España por efecto del cambio climático. Moreno, J. M. (ed.), pp. 65-112. Ministerio de Medio Ambiente.

Wessel, W. W., Tietema, A., Beier, C., Emmett, B. A., Peñuelas, J., Riis-Nielsen, T. 2004. A qualitative ecosystem assessment for different shrublands in Western Europe under impact of climate change, Ecosystems 7: 662-671. 